\title{
Correction to "A Novel Mitochondrial Complex of Aldosterone Synthase, Steroidogenic Acute Regulatory Protein, and Tom22 Synthesizes Aldosterone in the Rat Heart"
}

\author{
In the above article, [Bose HS, Whittal RM, Marshall B, Rajapaksha M, Wang NP, Bose M, \\ Perry EW, Zhao Z-Q, and Miller WL (2021) J Pharmacol Exp Ther, 377: 108-120; DOI: \\ https://doi.org/10.1124/jpet.120.000365], Tables 2 and 3 were omitted due to a compositor \\ error. The tables are provided below.
}

TABLE 2

Two hundred ninety-kilodalton complex from 2D native gradient PAGE

\begin{tabular}{llcc}
\hline Accession No. & \multicolumn{1}{c}{ Protein } & MS/MS & No. of Unique Peptides \\
\hline 113205888 & Malate dehydrogenase & 190 & 2 \\
2168 & Aldehyde dehydrogenase & 171 & 2 \\
56993 & StAR & 105 & 1 \\
19961 & Tom22 & 105 & 2 \\
129378 & P450c11AS & 94 & 1 \\
\hline
\end{tabular}

TABLE 3

One hundred ten-kilodalton complex from 2D native gradient PAGE

\begin{tabular}{llcr}
\hline Accession No. & Protein & MS/MS & No. of Unique Peptides \\
\hline 56993 & StAR & 105 & 1 \\
19961 & Tom22 & 105 & 2 \\
129378 & P450c11AS & 124 & 3 \\
\hline
\end{tabular}

The HTML and PDF versions of the article have been corrected.

The compositor apologizes for any inconvenience this error has caused. 